\title{
The NeCessity Of PleAding Elements in Private ANTITRust Conspiracy Claims
}

\author{
Max Huffman*
}

\section{INTRODUCTION}

The use of private actions to vindicate public rights is a perplexing difficulty in the enforcement of laws relating to economic regulation. Private antitrust enforcement presents a particularly dramatic exampleone that has captivated scholars for decades, and which remains a subject of vociferous debate.' The challenge is an institutional one. At bottom, private antitrust enforcement presents the danger of incentives misaligned

* Counsel, Robbins, Russell, Englert, Orseck, Untereiner \& Sauber LLP. Visiting Associate Professor, West Virginia University College of Law, Fall 2007. Beginning Fall 2008, Associate Professor, Indiana University School of Law-Indianapolis. This Article began as an academic amicus curiae brief supporting the petitioners in Bell Atlantic Corp. $v$. Twombly, 127 S. Ct. 1955 (2007) (No. 05-1126), with the financial support of my thenemployer, the University of Cincinnati College of Law. Primary thanks are due to Richard R. Huffman for his continuing guidance in life and work. Thanks also to Scott Dodson, Roy T. Englert, Jr., Patricia V. Galvan, Peter Richman, Letha Schwiesow, D. Daniel Sokol, Suja Thomas, and Elizabeth Thornburgh for edits and suggestions. All errors are my own.

1. The extent of the appropriate remedy for a private suit is one area of debate. See, e.g., Herbert Hovenkamp, The antitrust Enterprise (2005); Richard Posner, ANTITRUSt Law (2d ed.) (2002); Robert H. Lande, Five Myths About Antitrust Damages, 40 U.S.F. L. REV. 651, 651 (2006) (attacking the conventional wisdom that treble damages remedies over-deter); William H. Page, The Scope of Liability for Antitrust Violations, 37 STAN. L. REV. 1445, 1450-52 (1985) (demonstrating that optimal deterrence analysis supports treble damages liability in conjunction with procedural limitations on suit). That debate assumes meritorious claims. Another difficulty is the danger of non-meritorious strike suits. See, e.g., William H. Wagener, Note, Modeling the Effect of One-Way Fee Shifting on Discovery Abuse in Private Antitrust Litigation, 78 N.Y.U. L. REv. 1887, 189193, 1921 (2003). Cf. Posner, supra, at 275 \& n.8 (noting the "class action extortion" problem). On the other hand, commentators have emphasized the importance of the private suit in the overall enforcement scheme. See generally Steven C. Salop \& Lawrence J. White, Economic Analysis of Private Antitrust Litigation, 74 GEO. L.J. 1001, 1001 \& nn.1-3 (canvassing authorities). 
from the rationales for antitrust enforcement. ${ }^{2}$ The solution is a combination of substantive and procedural refinements to realign the incentives. $^{3}$

On the substantive side, courts and scholars have long recognized that parallel conduct by horizontal competitors-those competing in the same geographic and product markets and at the same level of the chain of distribution-does not raise red flags about the possibility of illegal concerted action. ${ }^{4}$ That understanding underlies decades of Supreme Court precedent, dating back at least to the opinion of Justice Clark in Theatre Enterprises, Inc. v. Paramount Film Distribution Corp., ${ }^{5}$ and continuing through cases such as Matsushita Electric Industrial Co. v. Zenith Radio Corp., Brooke Group Ltd. v. Brown \& Williamson Tobacco Corp. ${ }^{7}$ and most recently, Bell Atlantic Corp. v. Twombly. ${ }^{8}$ According to the Court in Matsushita, Sherman One requires a theory of the plaintiff's case that "tends to exclude the possibility that the alleged conspirators acted independently." The more recent decisions also recognize another reality that has informed antitrust decision-making since at least the neo-classical economic revolution in the field beginning in the 1960's. Litigation in general, but especially onerous, complex litigation that characterizes most private-plaintiff suits under section 1 of the Sherman Act, ${ }^{10}$ can be a massive expenditure of productive resources. It is dead-weight loss that cannot be justified if the conduct complained of is most likely innocent. ${ }^{11}$

Procedural issues regarding private plaintiffs' access to courts arise as well. The well-understood substantive principles regarding antitrust conspiracies are met with equally well-known dictum regarding the method

2. See Max Huffman, A Standing Framework for Private Extraterritorial Antitrust Enforcement, 60 SMU L. REV. 103, 114 (2007) (discussing the self-interest that motivates private plaintiffs).

3. Id. at 113 \& n. 70 (describing "optimizing" remedies that both deter and compensate appropriately).

4. See C. Brien Dillon, Similarity of Prices with Those of Competitors, in SOUTHWESTERN LEGAL Foundation 1958 INSTITUTE ON ANTITRUST LAWS 23, 30-32 (1958) (canvassing Supreme Court case law and enforcement authorities' positions and concluding conscious parallelism is not sufficient to establish a conspiracy).

5. 346 U.S. 537 (1954).

6. 475 U.S. 574 (1986).

7. 509 U.S. 209 (1993).

8. 127 S. Ct. 1955 (2007).

9. 475 U.S. at 588.

10. 15 U.S.C. $\S 1$ (2000 \& Supp. V 2005).

11. See Richard A. Epstein, Motions to Dismiss in Antitrust Cases: Separating Fact from Fantasy, 3-4 (AEI-Brookings Joint Center for Regulatory Studies, Related Publ'n 0608,2006 ). Of course, if private litigation offers sufficient benefits in the form of deterrence or compensation, the twin goals of private antitrust enforcement the loss is justifiable. See Huffman, supra note 2, at 107. There is reason to be skeptical on that front, however. See infra Part III.A. 
of pleading cases in federal court. Justice Black in Conley v. Gibson ${ }^{12}$ placed a gloss on Federal Rule of Civil Procedure $8,{ }^{13}$ holding that so long as any statement of facts could be proved consistent with the allegations a plaintiff made in its complaint, the complaint was sufficient to survive a motion to dismiss. That rule-itself a staple of Supreme Court doctrine, and reaffirmed recently in cases such as Leatherman v. Tarrant County Narcotics Intelligence \& Coordination Unit ${ }^{14}$ and Swierkiewicz v. Sorema $N . A{ }^{15}$ - could, if taken literally, have extraordinary and far-reaching consequences. A plaintiff could plead that "the sky is blue," and nonetheless be entitled to discovery, because it is possible to prove facts consistent with the sky being blue that would provide a basis for relief. ${ }^{16}$

There is obvious tension between concerns for false positives in private Sherman One suits and traditional understandings of ease of access to courts for private plaintiffs. That tension presents certain neat coincidences. The modern conceptions of both schemes, tracing back to Theatre Enterprises and Conley, are both creatures of the last halfcentury. ${ }^{17}$ Both schemes provide mechanisms-one procedural, one substantive-meant to compensate for injury and deter injurious conduct. Both present dangers of abuse that can summon drastic social ills. But the two schemes also dovetail neatly in a demonstration of Sir Henry Maine's famous statement that "substantive law has at first the look of being gradually secreted in the interstices of procedure." 18 Together, they

12. 355 U.S. 41, 45-46 (1957) (discussing the burden of proof on the movant in a motion to dismiss for failure to state a claim upon which relief may be granted).

13. FED. R. CIV. P. 8.

14. 507 U.S. 163 (1993).

15. 534 U.S. $506(2002)$.

16. Cf. Geoffrey C. Hazard Jr., From Whom No Secrets Are Hid, 76 Tex. L. Rev. 1665, 1668 (1998) (noting that "literal compliance with Conley" could consist of nothing more than the parties' names and a prayer for relief). Such a literal interpretation is, of course, a reductio ad absurdum of the language the Court employed in Conley. See Conley, 355 U.S. 41,45 (stating that a complaint should not be dismissed for failing to state a claim unless it appears beyond doubt that the plaintiff can prove no set of facts).

It also fails to heed the text of Rule 8 and writes out of the rule the power expressly granted to federal trial courts to dismiss plaintiffs' suits for "failure to state a claim upon which relief can be granted." FED. R. CIV. P. 12(b)(6). On the other hand, Professor Thomas argues carefully that the open-door approach to pleading followed by the more liberal understanding of Conley is commanded by the Seventh Amendment to the U.S. Constitution. See Suja Thomas, Why the Motion to Dismiss is Now Unconstitutional, MinN. L. REv. (forthcoming 2008) (draft at 7, available at http://ssm.com/abstract=1010062).

17. Theatre Enterprises, Inc. v. Paramount Film Distribution Corp., 346 U.S. 537, 544 (1954) (holding that earlier decrees against defendant for violating antitrust laws had little relevancy in present conspiracy action suit against defendant); Conley v. Gibson, 355 U.S. 41,47 (1957) (validating plaintiffs' private cause of action against railroad union for discriminatory practices).

18. Sir Henry S. Maine, Dissertations on Early Law and Custom 389 (John Murray, Albemarle Street 1883). 
prescribe the means by which potentially meritorious antitrust litigation can proceed to discovery and trial. The two schemes also permit litigation that is not based on any reasonable belief of wrongful conduct to be stopped before excessive waste occurs.

The Supreme Court in 2007 again affirmed the Rule 8 pleading standard and the principles underlying Theatre Enterprises and its progeny. In Bell Atlantic Corp. v. Twombly, ${ }^{19}$ the Court demonstrated that a middle ground exists in which the liberal pleading standard can be reconciled with the conservative substantive legal rule. Twombly has been called the sleeper case of the 2006 Supreme Court term. ${ }^{20}$ The reaction to Twombly was immediate and vociferous, with courts re-evaluating their approaches to motions to dismiss ${ }^{21}$ and many scholars expressing their views that the Court's interpretation of Rule 8 is an abandonment of the Conley rule. ${ }^{22}$

The interplay between Rule 8 and the requirements for proving a conspiracy under Sherman One came before the federal courts in the context of a private antitrust suit brought by end-user consumers that alleged a conspiracy among providers of local telephone and internet services. ${ }^{23}$ The plaintiffs argued that the defendants conspired both to prevent entry by other competitors into their respective service areas and not to enter into each others' service areas in competition with one another. ${ }^{24}$ The result, according to plaintiffs, was that the petitioners maintained monopolies in their geographic markets, causing injury to consumers. ${ }^{25}$ The allegations made in Twombly, if proved, would represent per se violations of Sherman One, and give rise to treble damages liability in a civil suit and jail time and criminal fines in a criminal proceeding. ${ }^{26}$

19. 127 S. Ct. 1955 (2007).

20. See Michael C. Dorf, The Supreme Court Wreaks Havoc in the Lower Federal Courts-Again, FindLAw, Aug. 13, 2007, http://writ.lp.findlaw.com/dorf/20070813.html (describing the impact of Twombly in contrast to its relative prior obscurity).

21. See, e.g., In re Elevator Antitrust Litig., No. 06-3128-CV, slip op. 8-9 (2d Cir. Sept. 4, 2007) (citing Twombly in holding that plaintiffs did not meet pleading standard for conspiracy claim). See also Dorf, supra note 20 (counting 457 cites to Twombly between the May 2007 decision date and the August 13 publication date of the column).

22. See id. See also A. Benjamin Spencer, Plausibility Pleading, 28-35 (forthcoming 2008) (on file with author) (criticizing Twombly for being "dramatically inconsistent" with the Federal Rules and Conley); Scott Dodson, Pleading Standards After Bell Atlantic Corp. v. Twombly, 93 VA. L. REv. IN BRIEF 121 (2007); Gregory P. Joseph, Supreme Court Rewrites Pleading Requirements (2007), available at http://www.scotusblog.com/movabletype/archives/Sup $\% 20 \mathrm{Ct} \% 20$ Rewrites\%20Pleading $\% 2$ ORules.pdf; Max Huffman, Casenote: Bell Atlantic v. Twombly, eCCP (May 2007), available at $\mathrm{http}: / / \mathrm{www}$. globalcompetitionpolicy.org/; Thomas, supra note 16.

23. Twombly, $127 \mathrm{~S}$. Ct. at 1961.

24. Id. at 1962 .

25. Id.

26. See 15 U.S.C. $\S 1$ (2000 \& Supp. V 2005) (felony to conspire to restrain commerce); 15 U.S.C. $\S 15$ (a) (2000) (treble damages for private plaintiffs). 
The local telephone industry at issue in Twombly has been marked by a complex history of regulated monopoly and, since 1996, torturous attempts at deregulation. ${ }^{27}$ The petitioners' respective "service markets" are the result of historical accident. Before February 8, 1996, when President Clinton signed the Telecommunications Act of $1996,{ }^{28}$ the monopolies in those markets were protected by state law. ${ }^{29}$ The patchwork of monopoly in local service areas traces itself to another massive antitrust suit, that one brought by the Antitrust Division of the U.S. Department of Justice against the American Telephone and Telegraph Company. The parties settled that suit in 1982 with a consent decree, and two years later, under Judge Green's Modified Final Judgment, ${ }^{30}$ AT\&T divested all its local telephony assets by spinning off the seven Baby Bells. A series of mergers among the Baby Bells produced four remaining competitors: BellSouth Corporation, SBC Communications, Inc., Qwest Communications International, Inc. and Verizon Communications, Inc., the defendants in Twombly. ${ }^{31}$

Deregulation in local telephony had the effect of creating two business models for firms seeking to provide local telecom services. One model is that of the traditional local telephone provider-the incumbent Baby Bells-which are commonly referred to as Incumbent Local Exchange Carriers (ILECs). Prior to deregulation, those providers maintained exclusive franchises in particular regions under state law. ILECs own and

27. According to economist Robert Crandall of the Brookings Institution, "no industry has been as ill-prepared to move from regulated monopoly to competition as the local telephone industry." Robert W. Crandall, Are We Deregulating Telephone Services? Think Again, BROOKINGS INSTITUTION, March 1997, available at http://www.brookings.edu/papers/1997/03telecommunications_crandall.aspx. See also Phil Weiser, Paradigm Changes in Telecommunications Regulation, 71 U. COLO. L. REV. 819, $837-41$ (2000) (discussing the need for evolving regulatory approaches in the telecom industry).

28. Telecommunications Act of 1996, Pub. L. No. 104-104, § 101(a), 110 Stat. 56 (codified in scattered sections of 47 U.S.C.).

29. See AT\&T Corp. v. Iowa Utilities Board, 525 U.S. 366, 371 (1999) (noting states, "typically granted an exclusive franchise in each local service area" until the 1990s). The Court in Twombly colorfully noted that "[t]he ILECs were born in this world" and they "doubtless liked the world the way it was." Twombly, 127 S. Ct. at 1972.

30. United States v. American Telephone, 552 F. Supp. 131 (D.D.C. 1982) (divestiture ordered to be effective Jan. 1, 1984) (approving consent decree that mandated, inter alia, equal access to interconnection facilities).

31. See Twombly v. Bell Atlantic Corp., 313 F. Supp. 2d 174 (S.D.N.Y. 2003). At the time suit was filed in Twombly, Bell Atlantic Corp. had not yet merged with Verizon Corp. Under another merger that was consummated in December 2006, Bell South Corp. and SBC Communications Inc. have now joined forces as AT\&T. See In re AT\&T Inc. and BellSouth Corp. Application for Transfer of Control, No. 06-74, Mem. Op. and Order 2-3 (filed Mar. 26, 2007), available at http://fjallfoss.fcc.gov/edocs_public/attachmatch/FCC-06-189A1.pdf (approving the proposed AT\&T and BellSouth merger). 
provide service using their local networks. ${ }^{32}$ The other business model is a class of competitors known as Competitive Local Exchange Carriers (CLECs) that seek to serve customers in competition with the ILECs now that the local markets have been opened to competition. CLECs usually compete by leasing network space from ILECs at rates prescribed by the Telecommunications Act of $1996 .^{33}$ The Twombly plaintiffs alleged that but for a conspiracy on the part of the ILEC defendants, CLECs would have entered into competition on a larger scale, and ILECs would have entered as CLECs into each others' territories. The resulting competition, according to plaintiffs, would have produced lower prices for consumers. ${ }^{34}$ Alleging a class of all users of local telephone and internet service from the passage of the Telecommunications Act until the time of filing suit, plaintiffs sought treble damages relief for the alleged harm. ${ }^{35}$

The trial court dismissed plaintiffs' complaint. In doing so, the court viewed the Rule $8(\mathrm{a})(2)$ pleading standard through the lens of the substantive Sherman One cause of action." ${ }^{36}$ Because "the Supreme Court has never held that proof of parallel business behavior . . . itself constitutes a Sherman Act offense," the court noted its responsibility to "distinguish between conduct that represents the natural convergence of competitors' market behavior, and conduct that appears to have been taken pursuant to an agreement."37 The court then turned to the "plus factor" framework that courts of appeals widely regard as defining the distinction between innocent parallel conduct and circumstantial evidence of conspiracy. It held the plus factors were shorthand for plaintiffs' responsibility to "assert facts that, if true, support the existence of a conspiracy.,

The district court held the specific allegations of the complaint were insufficient to amount to allegations of a conspiracy. ${ }^{39}$ While the plaintiffs alleged that the defendants' territorial markets appeared gerrymandered, the court observed that was the result of historical accident. Parallel refusal to be hospitable to entry by CLECs would be in each ILEC's unilateral best interest. Parallel conduct in not entering into competition with one another

32. See Iowa Utilities Board, 525 U.S. at 371.

33. Id. at 371-72 (citing 47 U.S.C. \$ 251(c) (1994)).

34. Twombly, 313 F. Supp. $2 \mathrm{~d}$ at 177-78 (alleging that the conspiracy forced the plaintiffs "to pay the supracompetitive rates of ILECs rather than the presumably lower rates that competition would have fostered").

35. Id. at 176 .

36. Id. at $179-82$.

37. Id. at 179 (quoting Theatre Enterprises, Inc. v. Paramount Film Distribution Corp., 346 U.S. 537, 544 (1954)).

38. Id. at 180-82. On plus factors generally, see 2 JOSEPH P. BAUER \& WILLIAM H. Page, KintNeR's Federal ANTITrust LaW $\S 11.5$ (Anderson Publishing Co. 2d ed. 2002). Cf. Matsushita Electric Industrial Co. v. Zenith Radio Corp., 475 U.S. 574, 588 (1986) (holding parallel conduct is insufficient to demonstrate a conspiracy).

39. Twombly, 313 F. Supp. $2 \mathrm{~d}$ at 179. 
was explainable by the fundamentally different nature of the CLEC business model ("essentially middlemen, buying network time from ILECs ... and selling it for a profit") from the ILEC business model. ${ }^{40}$ One specific allegation was of a quote by one defendant's CEO. The court held that the quote must be taken in the context in which it was made. Viewed in context, the quote spoke only to the defendant company's unilateral best interest. ${ }^{41}$ Finally, the court rejected an allegation that the defendants had conspired because it was conclusory. A unanimous panel of the Second Circuit reversed, holding that the Conley standard commanded the conclusion that factual allegations that were ambiguous as to whether conduct was legitimate or illegal were sufficient to survive a motion to dismiss. ${ }^{42}$

The Second Circuit applied more formalistically the rule that "a court would have to conclude that there is no set of facts that would permit a plaintiff to demonstrate that the particular parallelism was the product of collusion rather than coincidence." ${ }^{, 43}$ That standard was easily met by the plaintiffs' complaint in Twombly. It was possible, for example, that observed parallel conduct in failing to enter other ILECs' service areas as CLECs was the result of a market division agreement. It was possible that observed parallel inhospitality to entry by CLECs reflected a conspiracy to maintain the oligopoly to which the ILECs had grown accustomed.

So long as a conspiracy is "among the realm of plausible possibilities" from the complaint's allegations-which clearly it was, and would be except in the truly marginal circumstance-a court should deny a motion to dismiss. ${ }^{44}$ The court of appeals acknowledged the Supreme Court's rule that to survive summary judgment, a Sherman One plaintiff must provide evidence " "that tends to exclude the possibility' that the alleged conspirators acted independently., ${ }^{, 45}$ But it concluded that the Matsushita rule applied only at the summary judgment stage of proceedings.

The tension between the district court and the Second Circuit in Twombly is at bottom a tension between a pragmatic and a formalistic

40. Id.

41. Twombly, 313 F. Supp. 2d at 182-88. Richard Notebaert, the CEO of Quest, is quoted as stating that "competing as a CLEC 'might be a good way to turn a quick dollar but that doesn't make it right." Id. at 184.

42. Twombly v. Bell Atlantic Corp., 425 F.3d 99, 108 (2d Cir. 2005) (rejecting the argument "that antitrust complaints merit a more rigorous pleading standard, whether because of their typical complexity and sometimes amorphous nature, or because of the related extraordinary burdens that litigation beyond the pleading stage may place on defendants and the courts.").

43. Id. at 114 .

44. Id. at 111 .

45. Id. at 113-14 (quoting Matsushita Electric Industrial Co. v. Zenith Radio Corp., 475 U.S. 574, 588 (1986), which cites Monsanto Co. v. Spray-Rite Serv. Corp., 465 U.S. 752, 764). 
approach to pleading. The district court stated that its holding "is somewhat in tension with Federal Rule of Civil Procedure 8, which requires only a 'short and plain statement of the claim,' and allows plaintiffs to base their complaints on statements of ultimate facts. ${ }^{, 46}$ For its part, the Second Circuit recognized:

that a balance is being struck here, that on one side of that balance is the sometimes colossal expense of undergoing discovery, that such costs themselves likely lead defendants to pay plaintiffs to settle what would ultimately be shown to be meritless claims, that the success of such meritless claims encourages others to be brought, and that the overall result may well be a burden on the courts and a deleterious effect on the manner in which and efficiency with which business is conducted. ${ }^{47}$

The Supreme Court reversed the Second Circuit, holding in an opinion by Justice Souter that the complaint did not contain enough facts to cross the line from a mere possibility of illegal conspiratorial activity into the arena of "plausibility." tension between Rule 8 and the leading case interpreting the rule, Conley, and what it concluded was the need to protect defendants against frivolous antitrust litigation, the Court simply wrote the heart of Conley out of the books. Perhaps the most remarkable for having been penned by Justice Souter, one of the Court's more liberal members, the Court held that the famous "no state of facts" standard from Conley "after puzzling the profession for 50 years . . has earned its retirement., ${ }^{49}$

This Article undertakes a positivist justification of the rule announced in Twombly. Part II concentrates on the procedural questions that arise at the motion to dismiss stage of litigation. Federal Rule of Civil Procedure 8 codifies a standard of pleading under which complaints must both provide proper notice to the defendants-a universally accepted basis for the pleading requirement-and show pleaders' entitlement to relief-a much more controversial proposition. ${ }^{50}$ The "notice" requirement is not terribly vigorous. The "demonstration" requirement is what keeps Rule 8 from being an open door. It also comports with the plain language of Rule 8 and the motion to dismiss construct of Rule 12(b)(6). ${ }^{51}$ Rule 8(e) (formerly

46. Twombly, 313 F. Supp. $2 \mathrm{~d}$ at 180 (internal quotations omitted).

47. Twombly, 425 F.3d at 117.

48. Bell Atlantic Corp. v. Twombly, 127 S. Ct. 1955, 1965-66 (2007).

49. Id. at 1969.

50. See, e.g., Christopher M. Fairman, The Myth of Notice Pleading, 45 ARIZ. L. REV. 987 (2003) (arguing that the pleading rules exist to provide notice only).

51. See FED. R. CIV. P. 8(a), 12(b)(6). 
$8(\mathrm{f})$ ) is also relevant. It prescribes, simply, that district courts must use their discretion to do "justice." 52

Part III examines the implications for the private Sherman One claim of the new understanding of Rule 8. Viewing the pleading requirement through the lens of the governing substantive law, in order to plead Sherman One properly a plaintiff's factual allegations must create an inference of a conspiracy. To survive a motion to dismiss, a plaintiff must plead plus factors, which are facts "tending to exclude the possibility" that each defendant acted in its unilateral best interest. Couching plaintiffs' pleading responsibility in this manner makes clear that the Twombly rule does not apply uniquely to Sherman One litigation. It is trans-substantive. It is the substantively complex nature of the Sherman One claim that gives rise to any particular difficulties for private litigants. ${ }^{54}$ Part II continues to consider anecdotes of pleading practice in the Sherman One context in the lower courts since Twombly.

\section{The Federal Pleading AND Dismissal Scheme}

Rule 8 controls the sufficiency of plaintiffs' statement of claims. ${ }^{55}$ Together with Rule 12(b)(6), it provides a mechanism for courts to dismiss claims. ${ }^{56}$ The rules require courts to construe pleadings "so as to do justice." ${ }^{.57}$ The standards exist to accomplish two primary ends. They mitigate the concern that a defendant-much like Kafka's character Josef K.-might be subjected to defending against suit without knowing what it did that gave rise to the claims. ${ }^{58}$ More controversially, Rules 8 and 12(b)(6) give district courts means to dismiss suits that are not justifiable in light of the governing substantive legal scheme. ${ }^{59}$

52. See FeD. R. CIV. P. 8(e) (as amended 2007).

53. Twombly, 127 S.Ct. at 1964.

54. See A. Benjamin Spencer, Plausibility Pleading (Washington \& Lee Legal Studies Paper No. 2007-17, 26-27, 2007) available at http://papers.ssm.com/abstract_id=1003874 (arguing that the substantive requirements for a Sherman One claim make pleading Sherman One more difficult than other civil claims); see also Dodson, supra note 22, at 124 (noting that "several courts have already interpreted [Twombly] beyond antitrust").

55. FED. R. CIV. P. 8(a) (listing the requirements for a pleading stating a claim for relief).

56. FED. R. Civ. P. 12(b)(6) (allowing dismissal for a "failure to state a claim upon which relief can be granted").

57. FED. R. CIV. P. 8(e).

58. Cf. Franz KafKa, THE TRIaL (Breon Mitchell trans., Schocken Books 1998) (1925).

59. See, e.g., Richard L. Marcus, The Revival of Fact Pleading Under the Federal Rules, 86 CoLUM. L. REv. 433, 436 (1986) (arguing the purpose of pleading should be to better enable courts to decide cases on the merits); see also Allan Ides, Bell Atlantic and the Principle of Substantive Sufficiency Under Federal Rule of Civil Procedure 8(a)(2): Toward a Structured Approach to Federal Pleading Practice, 243 F.R.D. 604, 607 (2007) 


\section{A. The Relevant Federal Rules}

The Federal Rules are to be interpreted like federal statutes, according to plain language principles of interpretation. The Supreme Court unanimously held in Leatherman that Rule 8 "meant what it said."60 The rules, then, are not subject to amendment by judicial interpretation. ${ }^{61}$ The plain language of Rule 8 and Rule 12 provide substantial ammunition supporting the Court's decision in Twombly strictly to curtail the Conley rule.

The preeminent treatise on federal procedure notes that the broadest interpretation of the Conley dictum (the "sky is blue" allegations) cannot be the rule. ${ }^{62}$ Professor Miller notes that "a bare averment that the pleader wants compensation and is entitled to it" is insufficient. ${ }^{63}$ That understanding of Rule 8 respects the requirement contained in the rule that a plaintiff make "a short and plain statement of the claim showing the pleader is entitled to relief." $"$ Despite Conley, the Supreme Court held in 2005-its most recent prior analysis of the Rule 8 standard-that a plaintiff must allege facts making out each element of its claim.

In Dura Pharmaceuticals, Inc. v. Broudo, ${ }^{65}$ the Court considered the standards for pleading a private plaintiff claim for a violation of the federal securities laws. The substantive claim at issue in Dura was a violation of section 10(b) of the Securities Exchange Act of 1934 and SEC Rule 10b-5. The claim required proof of six elements, one of which is "loss causation." 66 Loss causation is the existence of a proximate causal link

(discussing three rules governing pleading under Rule 8 including notice, ensuring the viability of the claim, and the requirement that the claim be premised on a "factual transaction and not simply on an abstract invocation of the law"). Of course, the rules are not written on a blank slate. The Federal Rules operate against a constitutional backdrop. It is possible the Constitution has more stringent standards than does the text of Rules 8 and 12 for permitting plaintiffs to have access to federal court. See Thomas, supra note 16, at 6-7 (arguing "the Supreme Court was wrong to state that Congress and the rule-makers could impose essentially limitless requirements upon plaintiffs at the pleading stage").

60. Leatherman v. Tarrant County Narcotics Intelligence \& Coordination Unit, 507 U.S. 163, 168 (1993).

61. See id.; see also Pavelic \& LeFlore v. Marvel Entertainment Group, 493 U.S. 120, 123 (1989) ("We give the Federal Rules of Civil Procedure their plain meaning, and generally with them as with a statute, when we find the terms unambiguous, judicial inquiry is complete ...." (internal quotations and citations omitted)).

62. Charles A. Wright \& Arthur R. Miller, Federal Practice \& Procedure $\S$ $1216,235-36$ (3d ed. 2004) (interpreting Rule 8(a)).

63. Id.

64. FED. R. Civ. P. 8(a)(2); see Brownlee v. Conine, 957 F.2d 353, 354 (7th Cir. 1992)

(holding that facts alleged must "outline or adumbrate" a claim).

65. Dura Pharmaceuticals, Inc. v. Broudo, 544 U.S. 336 (2005).

66. Id. at 341 (citing 15 U.S.C. $\S 78 \mathrm{j}(\mathrm{b})$ and 17 C.F.R. $\$ 240.10 \mathrm{~b}-5$ ). 
between a material misrepresentation and the plaintiff's loss. ${ }^{67}$ Although the Private Securities Litigation Reform Act governs claims under Rule $10 \mathrm{~b}-5$ and imposes a heightened pleading standard on those claims, ${ }^{68}$ the Court "assume[d], at least for argument's sake, that neither the Rules nor the securities statutes impose any special further requirement in respect to the pleading of proximate causation or economic loss." ${ }^{.69}$ In Dura, Rule 8 and Conley governed the pleading issue. The Court held that the notice requirement from Conley was not satisfied because the complaint did not contain allegations going to an essential element-one that the plaintiff would be required to prove at trial- - of the plaintiff's claim. ${ }^{70}$

It is interesting that, after the Court's unanimous statements in Leatherman and Swierkiewicz that Rule 8 is subject to plain-language interpretation, the Dura Court relied for its holding on a judicial gloss from Conley." In Dura, Rule 8's textual requirement that the plaintiff "show[] entitle[ment] to relief" would have been a sufficient basis for the holding. By contrast, Dura is harder to justify based on a lack of notice. The "notice" goals Conley grafted onto Rule 8 were met in Dura. ${ }^{72}$

The Second Circuit in Twombly gave Dura only passing mention. It preferred the Court's 2002 decision in Swierkiewicz v. Sorema N.A. ${ }^{73}$ which held that a plaintiff need not plead around a burden-shifting framework for a Title VII claim. The Title VII complaint at issue in Swierkiewicz was sufficient even if the plaintiff did not plead a lack of non-discriminatory reasons for its disparate treatment. ${ }^{74}$

In one sense, the Title VII claim in Swierkiewicz makes a facially attractive analogy to the Sherman One suit. In a suit under Title VII, a plaintiff can claim he or she was treated differently than was another employee, who is not a member of a protected class. The employer then has the burden to demonstrate a legitimate, non-discriminatory reason for the disparate treatment. Only if the employer does so must the plaintiff

67. Id. at 341.

68. See Tellabs, Inc. v. Makor Issues \& Rights, Ltd., 127 S. Ct. 2499, 2508 (2007) (citing 15 U.S.C. $\S 78 \mathrm{u}-4(\mathrm{~b})$ ).

69. Dura, 544 U.S. at 346.

70. Id. at 346.

71. See FED. R. Civ. P. 8(a)(2) (plaintiff must make a "showing that the pleader is entitled to relief"). Commentators, too, have preferred Conley's gloss to the text of Rule 8 . See Fairman, supra note 50, at 988 (citing Rule 8(a) for the proposition that a complaint need only put the defendant on notice).

72. It is unclear how the failure to plead "loss causation" creates a notice problem for a $10 \mathrm{~b}-5$ defendant. That element has nothing to do with the conduct of the defendant and everything to do with the circumstances of the plaintiff. $C f$. Ides, supra note 59 , at 612 (notice has nothing to do with the requirement of substantive sufficiency of a complaint).

73. Swierkiewicz v. Sorema N.A., 534 U.S. 506 (2002).

74. Id. at 511-12 (interpreting Title VII of the Civil Rights Act of 1964, 42 U.S.C. $\S$ 2000 e (1994 \& Supp. V 1999)). 
bring evidence to demonstrate that justification is pretextual. ${ }^{75}$ The conspiracy claim under Sherman One is analogous. A plaintiff must prove sufficient facts giving rise to an inference of conspiracy, and the defendants can rebut those facts with a non-conspiratorial justification for the conduct alleged. If the defendants do so, presumably-like the Title VII plaintiffthe Sherman One plaintiff would argue the justification is pretextual.

Viewed more pragmatically, the Sherman One conspiracy claim is dramatically different from Swierkiewicz. ${ }^{76}$ The Title VII-type burden shifting analysis has no place in the context of Sherman One. The plaintiff's affirmative case includes the requirement that the plaintiff plead and prove that the conduct alleged was the product of a conspiracy. That requirement exists whether or not the defendant provides an alternate explanation. The distinction is made clearer by noting Justice Thomas's admonition in Swierkiewicz that "the McDonnell Douglas framework does not apply in every employment discrimination case." ${ }^{17}$ That is much in contrast to the Sherman One standard. The requirement that a plaintiff plead and prove that conduct was the result of a conspiracy is immutable.

The reason Swierkiewicz does little to inform the Sherman One standard is perhaps best understood as a policy distinction underlying the respective substantive legal rules of Title VII and Sherman One. As in Conley, itself an employment-rights case, McDonnell Douglas and Swierkiewicz reflect a policy decision favoring workers in protected classes by presuming discrimination from a showing of disparate treatment. The antitrust rules do not presume a conspiracy from allegations of parallel conduct. They presume legitimate business justifications exist for firms' conduct. ${ }^{78}$

It is easy to be misled by the language the Supreme Court used in Conley to gloss the Rule 8 standard. Under the "sky is blue" pleading theory, so long as a plaintiff's complaint did not affirmatively demonstrate the lack of entitlement to relief, the motion to dismiss would be denied. Another dean of federal civil procedure, Professor Hazard, stated that view

75. See McDonnell Douglas Corp. v. Green, 411 U.S. 792, 802-03 (1973).

76. But see Bell Atlantic Corp. v. Twombly, 127 S. Ct. 1955, 1982 (2007) (Stevens, J., dissenting); Dodson, supra note 22, at 127-28; Spencer, supra note 54, at 42-43.

77. Swierkiewicz, 534 U.S. at 511.

78. Cf. Epstein, supra note 11, at 3-4 (noting the danger of drawing negative inferences from neutral conduct); Twombly, 127 S. Ct. at 1964 . Commentators who consider Twombly in tension with Swierkiewicz do not address this distinction. See Dodson, supra note 22, at 127-28. This distinction prevents reconciling the apparent tension between Twombly and the Sherman One claim on the one hand, and Swierkiewicz and the Title VII claim on the other, by either reinterpreting Sherman One to involve burden shifting or reinterpreting Title VII to include the lack of a non-discriminatory reason for the employment decision as an element of the plaintiff's affirmative case. The first would improperly increase the risk of false positives (see infra Part III) while the second would undermine the Title VII claim. 
this way: "Literal compliance with Conley $v$. Gibson could consist simply of giving the names of the plaintiff and the defendant, and asking for judgment.",79

Surely Conley did not announce such a non-standard. If it did, it was dictum, as the complaint in Conley easily satisfies even the more stringent standard the Court recognized in Dura and Twombly. ${ }^{80}$ More importantly for the purposes of this Article, Dura and Twombly clearly require the pleading of elements of a claim. The elements are the "showing" that the plaintiff is "entitled to relief." 81

Looking beyond the plain text of Rule 8 (and beyond the glosses imposed by courts following Conley), commentary by Judge Charles Clark, the "architect" of the federal rules, and his contemporaries supports interpreting Rule 8 to require plaintiffs to plead elements. The thrust of Rule 8, to Judge Clark, was the avoidance of detail in pleadings-not the elimination of a requirement that the plaintiff "state a claim." to New Jersey Supreme Court Justice Arthur T. Vanderbilt, analyzing the Federal Civil Rules,

the objective of reaching an issue of law or of fact in two or at the most three simple pleadings has been attained but not at the sacrifice of stating the elements of a claim or defense .... The grand objective of the movement for simplified procedure by rules of court is the elimination of the interminable prolixity and absurd technicalities of special pleading - not by abandoning stating the essentials of a cause of action or of a defense, but by doing so in 'simple, concise and direct' terms. ${ }^{83}$

Others noted the importance of following the text of Rules 8 and 12. "A claim for which relief can be granted is a claim which is cognizable in law." 84 Another commentator decried interpretations of Rule 8(a)(2) that

79. Geoffrey C. Hazard, supra note 16 , at 1685 .

80. See Conley v. Gibson, 355 U.S. 41, $42-43$ (1957) (paraphrasing the complaint). Any realistic appreciation of Conley must acknowledge Justice Black's frustration with shenanigans by unions in avoiding their Railway Labor Act obligations to represent black members fairly. The opinion begins, "Once again [black] employees are here under the Railway Labor Act asking that their collective bargaining agent be compelled to represent them fairly. In a series of cases . . . this Court has repeatedly ruled that an exclusive bargaining agent under the Railway Labor Act is obligated to represent all employees in the bargaining unit fairly and without discrimination on the basis of race ...." Id. at 42 .

81. Rule 12(b)(6) provides further support for the plain-language interpretation of Rule 8(a). If the broadest understanding of the Conley gloss were law, it would write out of the federal rules the power to dismiss cases which Rule 12(b)(6) expressly grants.

82. Charles E. Clark, Special Pleading in the "Big Case", 21 F.R.D. 45, 52 (1957).

83. Statement of Judge Hall, in Claim or Cause of Action, 13 F.R.D. 253, 264-65 (1952) (quoting a letter from Judge Vanderbilt).

84. Statement of Judge Mathes, in Claim or Cause of Action, 13 F.R.D. 253, 265 (1952). 
emphasized liberal pleading at the expense of the plain language of the rule. "Those words 'showing that the pleader is entitled to relief' seem to have been read out of the Rule ...." 85

\section{B. Application to "The Big Case"}

Even advocates of liberal pleading practice emphasize the necessity that a complaint put the defendant on notice of the claims against it. Indeed, "notice" is the preferred justification for the pleading standard. Professor Fairman favors a less stringent pleading standard, but nonetheless recognizes that the notice requirement is what precludes a plaintiff's resort to alleging legal conclusions, rather than facts supporting the claims. "Legal conclusions do not comport with a notice standard." Professor Ides advances another justification for the prohibition of pleading legal conclusions. He argues that "the complaint must place the claims asserted within the context of a factual narrative." $\$ 88$ Ides derives his view from some combination of Rule 8's requirement of a "showing" of entitlement to relief and the Article III "case or controversy" requirement for a claim in federal court. ${ }^{89}$

If one looks only to "Form 9," the model form in the Federal Rules for a complaint alleging negligence, ${ }^{90}$ it might appear that conclusory allegations are always permitted. ${ }^{91}$ Form 9 establishes as a matter of law that a complaint alleging the defendant "negligently drove" is sufficient. Alleging "negligence" is certainly alleging a legal conclusion. ${ }^{92}$ Form 9 is not terribly informative as to the problem of pleading "the big case" such as a Sherman One conspiracy. "Negligently drove" describes a narrow, generally agreed-upon set of circumstances. The allegation provides notice to the party who is alleged to have negligently driven what generally, if not

85. Statement of Moses Laskey, in Claim or Cause of Action, 13 F.R.D. 253, 268-69 (1952).

86. Judge Clark's term. Clark, supra note 82 , at 45 . Judge Clark believed the rules applied equally in the context of massive complex litigation, including antitrust claims. Id. at 52. See also Mark C. Weber, The Federal Civil Rules Amendments of 1993 and Complex Litigation: A Comment on Transsubstantivity and Special Rules for Large and Small Cases, 14 REV. LiTig. 113, 113 (1994). But see Epstein, supra note 11, at 1-3 (noting that the Federal Rules were never meant to deal with complex cases).

87. Fairman, supra note 50, at 999.

88. Ides, supra note 59 , at 608 .

89. Id. at 607 .

90. See FED. R. CIV. P. 84, Form 9. Form 9 is as a matter of law a sufficient complaint in negligence. It is notable for its brevity.

91. Id. See Dodson, supra note 22, at 127 (arguing Form 9 demonstrates conclusory allegations are necessarily sufficient); Spencer, Plausibility Pleading, supra note 54, at 38 (citing other examples of legal conclusions in the form complaints).

92. See id. 
what exactly, he or she is supposed to have done wrong. ${ }^{93}$ "Conspiracy," as is demonstrated in some depth within, at least under the antitrust laws, is a slippery concept. ${ }^{94}$

Judge Clark would have agreed that some line exists beyond which allegations are too conclusory to be sufficient. He considered it "settled" that "the pleader shows the facts and the court applies the legal conclusion., 995

The notice requirement distinguished Twombly from Swierkiewicz and Conley. In both of those cases, the defendants knew exactly what they supposedly had done wrong. The complaints alleged plaintiffs had been treated differently based on national origin and race, respectively. An additional allegation that there was no race or national-origin neutral justification for the defendant's conduct would not improve the defendants' understanding of what they did to aggrieve the plaintiffs.

The Sherman One claim is different. Allegations that a defendant "conspired" does not tell the defendant what conduct, from the limitless possible things corporations (acting through their agents) do, constituted the conspiracy. That is especially so in view of the imperfect and muchdebated definition of a Sherman One conspiracy. ${ }^{96}$ Answering a complaint and preparing a defense would require an internal investigation that would mirror the discovery process in litigation. ${ }^{97}$ Even that would not necessarily inform the defendant what conduct the plaintiff would seize on to support its claim. If notice concerns could justify the result in Dura, where the unpleaded element was a causal connection between the fraud and harm to the plaintiff-a subsidiary element in the $10 \mathrm{~b}-5$ claim - they are all the more pressing where the unpleaded element is the crux of what the plaintiff is supposed to have done wrong.

The notice concerns take on special significance in the context of massive commercial tort cases. The onerous nature of discovery gives plaintiffs "an in terrorem increment of the settlement value." Stamps v. Manor Drug Stores and Dura are securities fraud cases, but

93. See Ides, supra note 59, at 611-12 (range of conduct giving rise to "negligence" is sufficiently small). But see Spencer, supra note 54, at 38 (arguing "reckless" in Form 10 is indefinite).

94. See Ides, supra note 59, at 610 (although what constitutes "notice" does not vary with different kinds of claims, what kind of pleading is required to give that notice is variable; Form 9 does not inform the manner of pleading more complex claims); see also infra Part III. It is not outstanding to note that the distinction between conclusory "factual" allegations, which the forms approve, and conclusory legal allegations, which Twombly reiterates are insufficient, is an arbitrary one. Gray areas will exist. However, "conspiracy" and "agreement" under the antitrust laws is not within the gray areas.

95. Clark, supra note 82, at 52.

96. See infra Part III.

97. Cf. Bell Atlantic Corp. v. Twombly, 127 S. Ct. 1955, 1970 n.10 (2007).

98. Blue Chip Stamps v. Manor Drug Stores, 421 U.S. 723, 741 (1975). 
twice the Supreme Court has expressed the same concern for settlement leverage in the context of private antitrust litigation. In Associated General Contractors of California, Inc. v. California State Council of Carpenters, ${ }^{99}$ the Court noted that a district court retains discretion "to insist upon some specificity in pleading before allowing a potentially massive factual controversy to proceed." 100 The same is true in Twombly. Courts and commentators note "the costs of modern federal antitrust litigation"101 and the concerns, which private antitrust litigation presents in spades, of "asymmetric discovery costs." 102

One response is that district courts can use their powers over the discovery process to rein in those costs and abuses. The Twombly Court believed that response is too facile. ${ }^{103}$ Judge Easterbrook has argued that for a host of reasons, control of discovery by district judges is a marginally effective protection against abuses. If discovery is used to find the details of the claim because the complaint is sketchy, limiting areas of inquiry based on the contours of the cause of action is impossible. It is also not effective to confine areas of inquiry based on the likelihood of it producing fruit; judges have no way to know what the files of the recipient of discovery contain. Only truly ridiculous requests will be possible to contain. ${ }^{104}$ Another problem with relying on district judges to use their inherent powers to rein in discovery costs is "the increasing caseload of the federal courts." $"$ Even if judges were equipped to do it, close monitoring of years of pre-trial activities would bring the system to a halt. ${ }^{106}$

A more robust response is that the very circumstances giving rise to asymmetric discovery costs inure to defendants' benefit as well. Asymmetric discovery costs will exist in circumstances where information

99. 459 U.S. 519 (1983).

100. Id. at 528 n. 17 .

101. Car Carriers, Inc. v. Ford Motor Co., 745 F.2d 1101, 1106 (7th Cir. 1984).

102. Asymmetric costs incentivize abusive discovery requests by one party, because the other party has no way to retaliate with its own onerous requests. See Frank Easterbrook, Discovery as Abuse, 69 B.U. L. REV. 635, 637, 643 (1989); William H. Wagener, Note, Modeling the Effect of One-Way Fee Shifting on Discovery Abuse in Private Antitrust Litigation, 78 N.Y.U. L. REV. 1887, 1902-03 (2003).

103. Bell Atlantic Corp. v. Twombly, 127 S. Ct. 1955, 1967 n.6 (2007).

104. Easterbrook, supra note 102, at 638-39. The Twombly Court agreed. "[D]etermining whether some illegal agreement may have taken place between unspecified persons at different ILECs (each a multibillion dollar corporation with legions of management level employees) at some point over seven years is a sprawling, costly, and hugely time-consuming undertaking not easily susceptible to the kind of line drawing and case management that the dissent envisions." Twombly, 127 S. Ct. at 1967 n.6.

105. Car Carriers, 745 F.2d at 1106.

106. But see Suja Thomas, Why Summary Judgment Is Unconstitutional, VA. L. REV. (forthcoming 2008) (on file with author) (arguing the concern for expensive pretrial litigation is overblown). 
asymmetries are present as well. ${ }^{107}$ If it is more expensive to defend a private antitrust suit than it is to prosecute one, it is commensurately more difficult for a private antitrust plaintiff to learn what happened in order to draft its complaint, or to structure a document request or a deposition notice. This information asymmetry favoring defendants encourages a liberal pleading standard.

Three reasons-two primarily theoretical, one doctrinal-show otherwise. Noted commentators including Judge Bork and Professor Epstein have shown that error in antitrust litigation should be on the side of false negatives rather than false positives, because the market is able to correct for a failure to regulate but not for the loss caused by overregulation. ${ }^{108}$ That concern is greater in the context of private litigation than in the context of government enforcement because of the concerns for misaligned incentives. Also, Sherman One claims, more so than claims under other legal schemes that are better understood (like the auto accident in Form 9), raise the concern that plaintiffs are not able to exercise judgment about the likelihood that observed actions result from illegal conduct. ${ }^{109}$ They are therefore more likely to sue over innocent conduct, exacerbating the false positive concern. Finally, the doctrine supports stringent review of pleadings in large civil litigation to better align settlements and liability with actual bad conduct. ${ }^{110}$

Twombly, involving a purported class of all users of local telephone and Internet services against all of the Baby Bells, may have boasted a nuisance settlement value exceeding $\$ 10$ million. Given the potentially crippling liability the defendants faced, plaintiffs would have massive leverage in negotiations. The concern that underlies Blue Chip Stamps and

107. Thanks especially to Scott Dodson for demonstrating this point to me.

108. Epstein, supra note 11, at 4; RoBert Bork, The ANTITRUST Paradox 117 (rev. ed. 1993).

109. Empirical evidence supports the proposition that lay jurors are more likely to believe conduct is the result of an antitrust conspiracy than is consistent with a robust understanding of business conduct. See Barbara S. Swain, Presentation at the ABA Section of Antitrust Law, 55th Annual Spring Meeting: We All Had the Same Idea: How a Jury Considers Claims Under the Monsanto Standard (Apr. 18, 2007) (paper and slides on file with author). Analysis should be done of the relevance of that research to understanding decision-making by plaintiffs and the impact of that evidence on pleading private antitrust claims.

110. See, e.g., Associated Gen. Contractors v. California State Council of Carpenters, 459 U.S. $519,528 \mathrm{n} .17$ (1983). Built into the doctrinal view is the understanding that a plaintiff that does not know of illegal conduct has no right to conduct a fishing expedition in an attempt to find it. See DM Research, Inc. v. College of Am. Pathologists, 170 F.3d 53, 56 (1st Cir. 1999). Cf. Brian Fitzsimmons, Note, The Injustice of Notice \& Heightened Pleading Standards for Antitrust Conspiracy Claims: It is Time to Balance the Scale for Plaintiffs, Defendants and Society, 39 RUTGERS L.J. (forthcoming 2008) (draft at 2, on file with author) (arguing that a balance should be struck between denying plaintiffs access to needed facts and preventing the harm to defendants from discovery in meritless cases). 
Associated General Contractors is that settlements are made with no regard to defendants' actual liability. That danger was presented in Twombly. ${ }^{11}$

"The Big Case," a term coined by Judge Clark requires a "critical assessment of the costs and benefits of stopping litigation at the pleading stage relative to those of going forward with discovery." 12 That was what the Supreme Court meant in Associated General Contractors, when it recommended that district courts "insist upon some specificity in pleading" in large private antitrust cases. ${ }^{13}$

According to Federal Rule of Civil Procedure 8(e), "[a]ll pleadings shall be so construed as to do substantial justice." That injunction is an odd one. District courts are required (they do not have discretion) to use their discretion. The Rule 8(e) injunction is also result oriented, not process oriented. It insists that substantial justice be accomplished and does not limit a court's choices as to how to achieve it. ${ }^{114}$

Former Rule $8(\mathrm{f})$ tends to be applied to resuscitate a complaint to protect a plaintiff's cause of action. ${ }^{115}$ In Swierkiewicz, the Court quoted Rule 8(f) in passing while emphasizing the simplicity of the Rule 8(a) notice pleading standard. In Conley, the Court used Rule 8(f) for the same purpose. ${ }^{116}$ Neither Court discussed the rule in greater detail or found it necessary to invoke it to hold the complaints met the notice standard. Certainly, there is nothing about former Rule 8(f) that prevents its application as recommended here. Judge Keeton did so in Cash Energy v.

111. "The same rules of discovery that generate one or two days worth of litigation in simple contract disputes" can take "years if not decades" in the case of massive class action litigation against national companies like the Twombly defendants. Epstein, supra note 11, at 6. Cf. Paul J. Stancil, Atomism and the Private Merger Challenge, 78 TEMP. L. REV. 949, 996-99 (2005) (describing the "staggering" expense of defending against private antitrust suits in the merger context). Indeed, the Supreme Court was convinced.

That potential expense is obvious enough in the present case: plaintiffs represent a putative class of at least 90 percent of all subscribers to local telephone or high-speed Internet service in the continental United States, in an action against America's largest telecommunications firms (with many thousands of employees generating reams and gigabytes of business records) for unspecified (if any) instances of antitrust violations that allegedly occurred over a period of seven years.

Bell Atlantic Corp. v. Twombly, 127 S. Ct. 1955, 1967 (2007); Epstein, supra note 11, at 6.

112. Epstein, supra note 11 , at 12.

113. Associated General Contractors, 459 U.S. at 528 n.17.

114. Courts and defendants can also hang their hats on Federal Rule of Civil Procedure 1, which requires that the rules "be construed and administered to secure the just, speedy, and inexpensive determination of every action and proceeding."

115. Swierkiewicz v. Sorema N.A., 534 U.S. 506, 513-14 (2002); Conley v. Gibson, 355 U.S. 41,47 (1957).

116. Of course, Conley can only be understood by reference to the particular circumstances of that litigation. See supra note 80 . 
Weiner, ${ }^{117}$ a case involving common-law fraud claims in the context of a supposed violation of the Superfund statute. According to Judge Keeton, “'substantial justice,' may be read as requiring judges to exercise some degree of discretion rather than invariably applying the general rule of notice pleading." the context of the massive litigation at issue is reminiscent of Judge Keeton's wisdom in applying Rule 8(f), although the Supreme Court failed to invoke the rule. ${ }^{119}$

\section{The Substantive Law OF SHERman ONE}

Twombly does not state a new way to understand pleading procedure. ${ }^{120}$ It is an application of the plain language of Rule 8 to the complex substantive law of antitrust conspiracies. At a minimum, that means that the Twombly rule is trans-substantive. The prolixity of a complaint will depend on the complexity of the substantive rule of law being applied. ${ }^{121}$

\section{A. Parallel Conduct is Not Enough}

The Sherman One claim requires a showing of a conspiracy. That element has never been satisfied with a mere showing of competitors' parallel conduct. ${ }^{122}$

The rationale for requiring more than a showing of parallel conduct by competitors to state a Sherman One claim is simple. No matter what the level of competitiveness in an industry, economists know that firms acting rationally can be expected to behave in a parallel manner. Amici

117. 768 F. Supp. 892 (D. Mass. 1991).

118. Id at 897 . The approach is taken without citing authority other than the former Rule 8(f), and has not been followed by any court.

119. Commentators, too, have done surprisingly little to clarify Rule 8(e) (formerly 8(f)). Like the majority of courts invoking its language, commentators favoring simplified pleading standards cite the former Rule 8(f) in support. See, e.g., Fairman, supra note 55, at 993. None have invoked it in support of Judge Keeton's interpretation in Cash Energy.

120. But see, e.g., Kendall v. Visa U.S.A., Inc., No. 05-16549, Slip Op. 2191 n.5 (9th Cir. Mar. 7, 2008).

121. Cf. Ides, supra note 59, at 610 .

122. Arguing against the Twombly result, Professor Thomas contends that "evidence that the ILECs engaged in the same behavior against the CLECs, and also the same behavior of not competing with one another could demonstrate to a jury that the ILECs agreed to engage in this behavior .... [T] his parallel behavior could show agreement." Thomas, supra, note 16 (draft at 32). That is incorrect. Parallel conduct is not inconsistent with a conspiracy, but it is not indicative of -it in no circumstances "demonstrates"-a conspiracy. To permit a jury to infer an agreement from parallel behavior is indistinguishable from permitting the same jury to infer agreement from the fact that the sky is blue, which it seems clear no court has ever done. See supra notes 16, 79 . 
economists in Twombly argued that in a "perfectly competitive market, all firms charge the same price at all times." ${ }^{123}$ That is because in a competitive market, all firms are price takers. They all respond in the same manner to the same impulses, and none has the ability to raise prices above its costs. ${ }^{124}$

The same result occurs if the firms do have power over price as oligopolists in a concentrated industry-much more akin to the real circumstances in Twombly. ${ }^{125}$ Parallel conduct occurs perhaps for the same reason as in a competitive market, for example when regulatory developments or technological innovations affect all firms in the industry in the same manner. ${ }^{126}$ Parallel conduct also potentially occurs for a different, but also innocent, reason. Firms, like gas-station competitors on opposite street corners, may look two moves ahead and appreciate the effect their actions will have on their competitor, and vice versa. Those oligopolists know, and they know their competitors know, and they know their competitors know they know, ${ }^{127}$ that if they act as industry mavericks they will be less profitable than if they tacitly agree not to cut, or to increase, prices. ${ }^{128}$ That kind of coordination—although a contracts scholar might well call it an implied agreement-is not illegal. ${ }^{129}$

There are two primary justifications for permitting such tacit collusion. One, advanced by Professor Turner in his 1962 paper on the subject, holds that an oligopolist acting in its unilateral best interest is the same thing as tacit collusion, so to outlaw the latter would be to require

123. Cert.-Stage Brief of William Baumol et al. in Support of Petitioners at 8-9, Bell Atlantic Corp. v. Twombly, No. 05-1126 (U.S. 2007).

124. Id. at 7. This understanding is well developed in the case law. See e.g., Weit v. Cont'l Ill. Nat'l. Bank \& Trust Co., 641 F.2d 457, 463 (7th Cir. 1981) (stating parallel pricing in industries characterized by fungible products and comparable cost structures is not probative of conspiracy).

125. Indeed, oligopoly of some form is characteristic of "the vast majority of actual markets." BORK, supra note 108 , at 102.

126. See Weit, 641 F.2d at 463 (7th Cir. 1981) (citing and discussing Peveley Dairy Co. v. U.S., 178 F.2d 363 (8th Cir. 1949), for the proposition that regulated input prices provide an innocent rational explanation for parallel pricing behavior).

127. See Note, Conscious Parallelism: Fact or Fancy?, 3 Stan. L. Rev. 679, 680 (1951) ("Competition has been likened to a mutual confidence game, where each competitor is trying to outguess the other fellow.") (citing M. A. Adelman, Effective Competition and the Antitrust Laws, 61 HARV. L. REV. 1289, 1299 (1948)).

128. See Dennis W. Carlton, Robert H. Gertner \& Andrew M. Rosenfield, Communication Among Competitors: Game Theory and Antitrust, 5 GeO. MASON L. REV. 423, 428 (1997) (citing EdWARD ChamberlaIN, THE THEORY OF MONOPOLISTIC COMPETITION (1933)); Bork, The Antitrust Paradox, supra note 108, at 103 ("By such a process the rivals may work themselves up to the monopoly price (and the restricted output necessary to raise the price), jointly maximizing their profits, without ever once meeting surreptitiously ....").

129. Brooke Group Ltd. v. Brown \& Williamson Tobacco Corp., 509 U.S. 209, 227 (1993). 
irrational conduct. ${ }^{130}$ Professor Whinston recently demonstrated the difficulty that Turner recognized: "Can we tell [oligopolists] 'Do not tacitly collude'? Or 'Do not make your pricing decisions with regard to what your rivals do'?"'131 The concern is heightened when we consider the punitive nature of the Sherman One enforcement scheme. "[W]ould it be fair to send managers to jail for failing to follow such vague prescriptions?" 132 The private treble-damages remedy is no better, because of its punitive nature.

A second rationale for permitting tacit collusion, which is closely related to the first, turns on the difficulty of distinguishing between independent parallel activity and interdependent conduct. To an outside observer, the two are indistinguishable. For one example, imitating successful strategies of competitors is acting in parallel, but it is competitive, not anti-competitive. ${ }^{133}$ Far from being probably anticompetitive, parallel conduct by competitors is most likely the result of unilateral-and therefore legitimate-business decisions. ${ }^{134}$

This wisdom underlay the Supreme Court's 1954 decision in Theatre Enterprises, Inc. v. Paramount Film Distributing Corp., ${ }^{135}$ a case in many ways very similar to Twombly. In an opinion written by Justice Tom Clark, formerly the head of the Antitrust Division at the U.S. Department of Justice, ${ }^{136}$ the Court considered allegations that parallel refusal to permit "first-run" movies to be shown outside of densely populated metropolitan areas violated Sherman One. The defendants were a group of motion picture producers and distributors, including Paramount Film Distributing, Loew's, Inc., Twentieth-Century Fox, United Artists, Warner Brothers Pictures, and Columbia Pictures. ${ }^{137}$ Plaintiff was an operator of a suburban Baltimore theater, called the Crest, that was modern and well-appointed in every way but its location. ${ }^{138}$ All of the defendants rebuffed the plaintiff's efforts to obtain first-run movies, arguing that exclusive franchises were

130. See Donald F. Turner, The Definition of Agreement Under the Sherman Act: Conscious Parallelism and Refusals to Deal, 75 HARV. L. REv. 655, 692 (1962).

131. Michael D. Whinston, Lectures in Antitrust Economics 39, 52 (2006).

132. Id. at 52-53.

133. Cert.-Stage Brief of William Baumol et al. in Support of Petitioners at 8-9, Bell Atlantic Corp. v. Twombly, No. 05-1 126 (U.S. 2007).

134. Epstein, supra note 11, at 3. See also supra note 123.

135. 346 U.S. 537 (1954).

136. Justice Thomas C. Clark was the former head of the Antitrust Division of the U.S. Department of Justice. See Timeline of ANTITRUST ENFOrCEMENT Highlights at THE DEPARTMENT OF JUSTICE, http://www.usdoj.gov/atr/timeline.pdf (last visited Sept. 5, 2007).

137. Theatre Enterprises, 346 U.S. at 539, n.2.

138. Id. at 540 ("the Crest is a suburban theatre, located in a small shopping center, and served by limited public transportation facilities; and, with a drawing area of less than onetenth that of a downtown theatre, it cannot compare with those easily accessible theatres in the power to draw patrons."). 
necessary for their business, and plaintiff's inferior location made an exclusive franchise with that theater unattractive. ${ }^{139}$ Many of the defendants shared the same rational, non-conspiratorial explanation for their individual refusals to deal with the plaintiff in the market for first-run pictures. ${ }^{140}$ According to the Court, "The crucial question is whether respondents' conduct toward petitioner stemmed from independent decision or from an agreement, tacit or express .... [T] his Court has never held that proof of parallel business behavior conclusively establishes agreement or, phrased differently, that such behavior itself constitutes a Sherman Act offense." $" 141$

Procedurally, Theatre Enterprises is poor authority for the rule in Twombly at the motion-to-dismiss stage. The Court in Theatre Enterprises reached the un-outstanding conclusion that a refusal to grant a directed verdict for the plaintiff should be affirmed. ${ }^{142}$ But the Court's substantive rule on the definition of a Sherman One agreement provides substantial support for the result in Twombly. Conscious parallel conduct by competitors does not suffice to state a claim under Sherman One. Noted antitrust commentators such as Professor Turner have accepted the rule. "[C]onscious parallelism is never meaningful by itself . . . [It is] a neutral fact in the absence of evidence which would lead one to expect that price would have been different if truly independent decisions had been made. .143

Turner's proposition is by no means unchallenged among commentators in the modern era. The other side of the argument-most prominently advanced by Judge Posner-holds that consciously parallel conduct, where competing gas stations on opposite street corners raise and lower prices, seemingly in unison, sometimes several times a day, does actually reflect a meeting of the minds of those competitors, and should be treated as conspiratorial. ${ }^{144}$ Posner recognizes his approach is not the "traditional legal approach," and instead defines collusive pricing as an

139. Id. at 540 .

140. Id. at 540 ("the downtown theatres offer far greater opportunities for the widespread advertisement and exploitation of newly released features, which is thought necessary to maximize the overall return from subsequent runs as well as first-runs. The respondents, in the light of these conditions, attacked the guaranteed offers of petitioner, one of which occurred during the trial, as not being made in good faith. Respondents Loew's and Warner refused petitioner an exclusive license because they owned the three downtown theatres receiving their first-run product").

141. Id. at 540-41.

142. Id. at 541 .

143. Turner, supra note 130 , at 659.

144. Richard A. Posner, Oligopoly and the Antitrust Laws: A Suggested Approach, 21 StAN. L. REV. 1562, 1575 (1969); PoSNER,, supra note 1, at 94-96. Cf. Mark D. Anderson, Vertical Agreements Under Section 1 of the Sherman Act: Results in Search of Reasons, 37 U. Fla. L. Rev. 905, 934 (1985) (describing the Turner-Posner divide). 
economic construct. ${ }^{145}$ As Posner states, "From an economic standpoint it is a detail whether the collusive pricing scheme was organized and implemented in such a way as to generate evidence of actual communications." ${ }^{146}$ Professor Whinston points out, however, that there is neither clear understanding of what exactly constitutes tacit collusion. For example, is it tacitly collusive anytime prices in an oligopolistic industry exceed marginal cost? ${ }^{147}$ Recent game theoretic economic analysis, detailed by economists including Werden and Carlton, has offered a more nuanced understanding of consciously parallel pricing than the TurnerPosner divide demonstrates. ${ }^{148}$ However, from a doctrinal perspective, what is essential is that the Theatre Enterprises rule has been solidly etched into the body of Sherman One doctrine. ${ }^{149}$ Barring federal legislation, the doctrinal approach to conscious parallelism should remain unmolested. ${ }^{\text {iso }}$

It is a dangerous game to indulge the inference of a conspiracy based on facts, like parallel conduct, that more likely indicate legitimate unilateral conduct. As Professor Epstein has argued, such an inference presents two harms. One is the direct costs on the business of the particular defendants, and the dead weight economic costs of litigation. The other is the disincentives the inference would create for firms vigorously to compete, because all "business decisions would be colored" by the danger of Sherman One litigation. ${ }^{151}$ Those are precisely the concerns underlying Dura, Blue Chip Stamps and Associated General Contractors.

Firms faced with sanctions for acting in parallel would be acting rationally if they deliberately avoided the most efficient course of conduct--whether that be imitating competitors' winning strategies, or pricing in parallel so as not to give a competitor an advantage. Judge Bork

145. POSNER, supra note 1 , at 69.

146. Id. at 94 .

147. Whinston, supra note 131 , at 53-54 (answering in the negative. Whinston distinguishes theoretically between "dynamic strategies" and "static Cournot competition," but recognizes even that distinction is difficult to appreciate in practice).

148. See Gregory J. Werden, Economic Evidence on the Existence of Collusion: Reconciling Antitrust Law with Oligopoly Theory, 71 ANTITRUST L.J. 719, 759-80 (2004); Dennis W. Carlton, The Relevance for Antitrust Policy of Theoretical and Empirical Advances in Industrial Organization, 12 GEO. MASON L. REV. 47, 50 (2003); Carlton, Gertner \& Rosenfield, supra note 128, at 430-39; Willard K. Tom, Game Theory in the Everyday Life of the Antitrust Practitioner, 5 GeO. MASON L. REV. 457, 458-61 (1997) (discussing authorities).

149. See Bell Atlantic Corp. v. Twombly, 127 S. Ct. 1955, 1964 (2007); Theatre Enterprises, Inc. v. Paramount Film Distributing Corp. 346 U.S. 537, 541 (1954); Brooke Group Ltd. v. Brown \& Williamson Tobacco Corp., 509 U.S. 209, 227 (1993). See also E.I. du Pont de Nemours \& Co. v. FTC, 729 F.2d 128, 137-39 (2d Cir. 1984) (reversing FTC order based on consciously parallel conduct).

150. Cf. Dillon, supra note 4, at 53 ("Theatre Enterprises killed conscious parallelism as a legal doctrine; I hope you will make it your business to see that it stays buried.").

151. Epstein, supra note 11. 
argued that "[a] cluster of considerations require nonintervention in doubtful cases." 152 And, in a related context, "adjustment to shifting costs and demand is socially desirable, and it is best that appropriate responses be made as quickly as possible." ${ }^{, 153}$ A rule that penalizes firms (by exposing them to litigation beyond the motion to dismiss stage) for undertaking the rational response to stimuli, whether the actions of competitors or external to the market, risks increasing price rigidity and stifling other business decisions. That is all the more so where, as in the case of the definition of agreement under Sherman One, the substantive standards for liability remain vague. Whinston notes that under the Posner definition of agreement, "[f]alse positives are a real danger" because it is difficult even to define what qualifies, and to structure an effective remedy for tacitly collusive conduct. ${ }^{154}$

Those theoretical arguments are powerful. The expense of litigation creates a powerful disincentive to engage in conduct that might bring it about. ${ }^{155}$ Where that conduct is harmful, that is a good result. Where that conduct is beneficial, it is a grievous error. ${ }^{156}$

The theoretical explanation for the Twombly rule runs up against a criticism, however, which is that the danger of litigation apparently did not prevent the Twombly defendants from acting rationally in pursuit of their unilateral best interest in response to market stimuli. Where, then, is the chilling effect? One response to the criticism is that we have no way of knowing how many industries have been limited in their competitive vigor by the threat of litigation, or indeed, in what circumstances the very defendants in Twombly may have avoided pro-competitive conduct out of fear of litigation.

Another response to the criticism is merely one of fairness. Onerous litigation is a sanction in a very real sense, and sanctioning firms for what we want them to do makes no sense.

152. BORK, supra note 108 , at 133.

153. Id. at 388 (discussing the Robinson Patman Act).

154. Whinston, supra, note 131 , at 54 .

155. This proposition is generally accepted. See, e.g., Whinston, supra note 131, at 5455 ("Firms will naturally avoid placing themselves in positions that trigger antitrust intervention, whether monetary damages or restructuring, and this may lead them to shy away from cost reductions or product improvements that might improve their margins."); Cert.-Stage Brief, supra note 123, at 14-16 (discussing conduct by competitors that might appear conspiratorial but is highly beneficial, competitive conduct). What is less well understood, and perhaps impossible accurately to test, is the magnitude of the effect.

156. It is usually in the context of section 2 of the Sherman Act, 15 U.S.C. $\S 2(2000 \&$ Supp. V 2005), that courts and commentators discuss the concern for "false positives" preventing vigorous competition. See, e.g., Matsushita Electric Industrial Co. v. Zenith Radio Corp., 475 U.S. 574, 593-94 (1986). These arguments thus have all the more force in the context of Sherman Two litigation. 
Finally, Professor Fairman argued in 2003 that courts have required fact-based pleading in conspiracy claims long before Twombly. ${ }^{157}$ If so, it is the Second Circuit's rule that is the aberration, and the Twombly defendants would have made their business decisions based on expectations developed under the dominant approach courts took to pleading. ${ }^{198}$

The challenge is to distinguish those claims that are inappropriate sanctions for pro-competitive conduct-the false positives-from those that appropriately act as disincentives to harmful conduct. Courts and commentators understand that the height of competitive activity may look very much like conduct that violates Sherman One. ${ }^{159}$ The surest way is to enforce rigorously the Dura requirement that a plaintiff plead the elements of the substantive claim. In a nutshell, that is what Twombly now requires for private suits alleging antitrust conspiracies.

\section{B. $\quad$ Pleading Plus Factors}

In 1984 in Monsanto Co. v. Spray-Rite Services Corp.,${ }^{160}$ the Supreme Court refused to infer an agreement from conduct that occurs "in the normal course of business and do[es] not indicate illegal concerted action." ${ }^{.161}$ This is an application of the same rule that prohibits liability for parallel conduct. Instead, and for the various reasons discussed previously in this Article, "there must be evidence that tends to exclude the possibility that the [defendants] were acting independently." 162 The Court reiterated that requirement two years later, in the opinion that served as a capstone to the decades-old litigation in Matsushita Electric Industrial Co. v. Zenith Radio Corp. ${ }^{163}$ " $[\mathrm{A}]$ plaintiff seeking damages for a violation of $\S 1$ must present evidence 'that tends to exclude the possibility' that the alleged conspirators acted independently." ${ }^{164}$ That is a faithful rendering of Justice Clark's Theatre Enterprises rule.

157. Fairman, supra note 50, at 1011-21 (arguing this is a legally erroneous approach).

158. See infra notes 204-05 and accompanying text (discussing DM Research, Inc. v. College of American Pathologists, 170 F.3d 53 (1st Cir. 1999)).

159. See, e.g., Cosmetic Gallery, Inc. v. Schoeneman Corp., 495 F.3d 46, 52 (3d Cir. 2007) (discussing competitive conduct that appears to violate the Sherman Act).

160. 465 U.S. 752 (1984).

161. Id. at 763 (internal quotations omitted).

162. Id. at 764 .

163. 475 U.S. 574 (1986).

164. Id. at 588 (quoting Monsanto). Matsushita tells a compelling tale about the necessity to resolve claims early in litigation. Millions of dollars and dozens of years were spent on litigation in that case, only to learn that the plaintiffs' theory of liability was insufficient as a matter of law. See Matsushita Electric Industrial Co. v. Zenith Radio Corp, 475 U.S. at 576 (showing that the Matsushita lesson gives strong contextual support for the result in Twombly). 
Those rules are substantive rules of the law of conspiracies in antitrust, not procedural requirements imposed because of some particular feature of the antitrust claim. Such an account implies that the Twombly opinion is not a civil procedure opinion at all, but is important only from the perspective of the substantive antitrust law. That explains how Theatre Enterprises could have compelled the result in Twombly, although the issue arose at a very different stage of the litigation.

Procedurally, Dura commanded the conclusion-and Swierkiewicz did not undermine it-that the Twombly plaintiffs were required to plead allegations that satisfy the Matsushita and Theatre Enterprises rules. The question is, then, what about the state of the market for local telephone and Internet services makes parallel conduct in that market any more nefarious than in the vast majority of circumstances?

Allegations of facts that are neutral, or ambiguous, do not meet the standard. Commentators analyzing Matsushita agree that "proof of an agreement requires some evidence that is exclusively of agreement."165 Courts and commentators have stated the required showing for circumstantial evidence of conspiracy to be one of "parallel conduct plus"-with the "plus" representing allegations that make it unlikely the parallel conduct is based on a firm's pursuit of its unilateral best interest. ${ }^{166}$ Professor Epstein explained plus factors using the language of Monsanto. "A plus factor is any form of evidence that tends to exclude the possibility that individuals work independently."167 Whinston describes "evidence" that "increas[es] the likelihood that a price-fixing conspiracy is taking, or has taken, place." 168 Such plus-factor evidence is necessary when there is no direct evidence of a conspiracy, but where enforcement policy demands there be a way to prove a conspiracy with indirect evidence. ${ }^{169}$

165. 2 BAUER \& PAGe, supra note $38, \S 11.4$, at 59. Professors Bauer and Page demonstrate this concept graphically with a Venn diagram comprised of overlapping circles. If the leftmost circle represents evidence that indicates agreement, and the rightmost circle represents evidence that indicates independent action, the overlap represents evidence that is ambiguous as to whether it indicates agreement or independent action. "[E]vidence solely in [the overlap] is insufficient." Id. $\S 11.5$, at 59-60.

166. See Mitchael v. Intracorp, Inc., 179 F.3d 847, 858-59 (10th Cir. 1999) (describing plus factors); Werden, supra note 148, at 745 (locating the first use of the term "plus factors" in the Ninth Circuit's 1952 decision in C-O-Two Fire Equip. Co. v. United States, 197 F.2d 489 (9th Cir. 1952)).

167. Epstein, supra note 11, at 10-11 (citing Apex Oil Co. v. DiMauro, 822 F.2d 246 (2d Cir. 1987)).

168. Whinston, supra note 131 , at 39 .

169. Id. at 38-39. 
Notably, although the doctrine was argued to the Court in Twombly and has been discussed in the lower courts for decades, the Supreme Court did not expressly adopt the doctrine of plus factors. ${ }^{170}$

The idea of plus factors has long been understood by the Court. Theatre Enterprises recognized that "business behavior is admissible circumstantial evidence from which the fact finder may infer agreement." In Twombly, the Court came close to explicitly adopting the construct, twice quoting other sources (the Second Circuit's decision below and one of the parties' briefs) as referencing "plus factors," and in the now-famous footnote four defining additional circumstantial facts that might be sufficient to vault allegations of parallel conduct into allegations of a conspiracy. ${ }^{172}$ It is fair to read the Twombly opinion as giving implicit approval to an approach to implementing the Theatre Enterprises, Matsushita and Monsanto rules that has been followed in the lower courts for decades. With the deepening body of case law and scholarly commentary defining plus factors, an appropriate vehicle for the Court to consider them in greater depth may present itself in the near future.

It is good that the Court did not simply adopt wholesale the plus factor doctrine from the courts of appeals. Much remains to be decided to consider that framework sufficiently developed. Professor Whinston wrote about the definition of a Sherman One agreement generally, arguing that it is "paradoxical that the least controversial area of antitrust is perhaps the one in which the basis of the policy in economic theory is weakest." 173 That theoretical weakness invokes Judge Bork's concern for "fair warning" to a regulated entity-impossible "if the 'law' depends on the sympathies and prejudices of any one of the hundreds of federal judges before whom [a businessman] may find himself arraigned."174 Although Whinston did not adopt the terminology of plus factors, he described them as being represented by either structural evidence or behavioral evidence. ${ }^{175}$

Evidence that tends to exclude the possibility of unilateral conduct is not difficult to recognize at the margins. One example is the one plus factor that the Twombly Court appeared to approve in footnote four:

170. Bell Atlantic Corp. v. Twombly, 127 S. Ct. 1955, 1964 (2007). See Interstate Circuit v. United States, 306 U.S. 208 (1939); E. ThOmas Sullivan \& Jefrrey L. HARRISON, UNDERSTANDING ANTITRUST AND ITS ECONOMIC IMPLICATIONS 186-87 (3d ed. 1998). Special thanks to Roy Englert for this observation about Twombly.

171. 346 U.S. at 540. Compare Whinston, supra note 131, at 39 (noting that circumstantial evidence of conspiracy is divided into structural and behavioral evidence).

172. Twombly, 127 S. Ct. at 1965 n.4 (referencing "complex and historically unprecedented changes in pricing structure made at the very same time by multiple competitors, and made for no other discernible reason").

173. Whinston, supra note 131 , at 26.

174. BORK, supra note 108 , at 81 .

175. Whinston, supra note 131 , at $39-52$. 
"complex and historically unprecedented changes in pricing structure made at the very same time by multiple competitors, and made for no other discernible reason." factor is in the words, "for no other discernible reason." The difficult question in Twombly is precisely whether "other discernible reasons" for the ILECs parallel refusal to enter into competition as CLECs in one another's territories undid the plaintiffs' allegations that the refusal was irrational.

Plus factors have included a vague amalgam of matters, all of which are relevant (in the way the Federal Rules of Evidence define the term) to proof of conspiracy, but many of which fall far short of rising to the level of "tending to exclude the possibility" of unilateral conduct. Some of the facts pleaded in Twombly, including trade association involvement and oligopolistic market structure, have been considered plus factors. ${ }^{177}$ But the Court held they did not make it less likely that the defendants acted unilaterally, or more likely they conspired. ${ }^{178}$

The answer, such as it is, is to require plaintiffs to plead facts that, if true, give rise to a reasonable inference that the observed parallel conduct was the product of a conspiracy. The implications of this answer are more dramatic than they appear to be at first glance. The economic analysis of oligopoly theory, the modern understanding of which can be traced to Stigler's seminal 1964 article, "A Theory of Oligopoly," 179 turns on structural features of markets that make collusion more likely. ${ }^{180}$ But structural market features are neutral facts under a legal regime that requires "some setting suggesting the agreement necessary to make out a $\S$ 1 claim." of conspiracy, carving out from it the broad swath of conduct that is

176. Twombly, 127 S. Ct. at 1965 n.4 (citing Brief for Respondents 37 and Reply Brief for Petitioners 12).

177. See Apex Oil Co. v. DiMauro, 822 F.2d 246, $253-54$ (2d Cir. 1987).

178. Cf. Williamson Oil Co. v. Philip Morris USA, 346 F.3d 1287, 1319-20 (11th Cir. 2003) (holding that eleven plus factors show "nothing more than [evidence] that the tobacco industry is a classic oligopoly, replete with consciously parallel pricing behavior"); $c f$. Weit v. Cont'l Ill. Nat'l. Bank \& Trust, 641 F.2d 457, 463 (7th Cir. 1981) (holding that plus factors including opportunities to conspire and meetings among competitors are not sufficient to survive summary judgment on claim of conspiracy).

179. George J. Stigler, $A$ Theory of Oligopoly, 72 J. PoL. ECON. 44 (1964).

180. See id. at 44-56 (discussing and modeling market structures conducive to collusion); Andrew R. Dick, Identifying Contracts, Combinations and Conspiracies in Restraint of Trade, 17 MANAGERIAL \& DECISION ECON. 203, 208-11 (1996) (examining industry characteristics that assist in forecasting cartel activity); POSNER, supra note 1 at 69-93 (listing factors that make collusion more likely and factors that provide circumstantial evidence of collusion).

181. Twombly, 127 S. Ct. at 1966; c.f. E.I. du Pont de Nemours \& Co. v. FTC, 729 F.2d 128,139 (2d Cir. 1984) (stating that an oligopolistic industry structure "represents a condition, not a 'method'"). 
consciously parallel rather than explicitly conspiratorial. ${ }^{182}$ Legal doctrine thus narrows considerably, vis-à-vis economic theory, the sort of allegations that will suffice to state a Sherman One claim. ${ }^{183}$

As noted above, at the margins, facts that rise to the level of being plus factors are easy to define. The Twombly plaintiffs' quote from one defendant's CEO was most consistent with that defendant's making a unilateral business decision, but certainly a quote that was more concrete and damning ("we met and decided on prices")-perhaps from a disgruntled former employee-might be sufficient. Notably, Justice Stevens in dissent in Twombly argued discovery was essential to determine whether the CEO's quote was indeed neutral. ${ }^{184}$ Allegations of trade association involvement were neutral, but allegations of a secret meeting in a smoke-filled room would be indicative of a conspiracy. ${ }^{185}$ Allegations of joint refusal to enter one another's markets were neutral, but the same allegations of failure to enter, in a market in which the prevailing norm was vigorous entry and exit, might be very different. ${ }^{186}$ Allegations of parallel price structures are neutral, but allegations of parallel and irrational price structures might be sufficient. ${ }^{187}$ This description of the shades of gray in the plus factor framework demonstrates the impossibility of splitting hairs with a chain saw. ${ }^{188}$ The plus factor framework will always be difficult to

182. See In re High Fructose Corn Syrup Antitrust Litigation, 295 F.3d 651, 654-55 (7th Cir. 2002) (noting that "the statutory language" of Sherman One "is broad enough to encompass a purely tacit agreement to fix prices," but that the legal doctrine requires proof of an actual agreement, not just tacit coordination).

183. See POSNER, supra note 1, at 94 ("there is no distortion of accepted meanings in viewing tacit collusion as a form of concerted rather than unilateral activity").

184. See Twombly, $127 \mathrm{~S}$. Ct. at 1986-87 (Stevens, J., dissenting) (imagining that the CEO might have confessed to a conspiracy and arguing the only way to find out would be to depose him).

185. See Epstein, supra note 11, at 11. But see Dillon, supra note 4, at 25-26 (arguing that as a practical matter, such evidence is unlikely to surface in most cases. " $L$ 'espionnage type of conspiracy, where men from competing companies meet at midnight in a smokefilled hotel room, wearing long black robes and black hats, and reduce their collusive agreement to writing, is passé.").

186. Cf. Twombly, $127 \mathrm{~S}$. Ct. at 1972 (discussing the historical accident justification for the Gerrymandered service areas, which otherwise might be evidence of conspiratorial activity).

187. Id. at 1966 n.4 (citing both Respondent and Petitioner briefs which, in turn, suggest that "complex and historically unprecedented changes in pricing structure made at the very same time by multiple competitors, and made for no other discernible reason would support a plausible inference of conspiracy.").

188. Cf. E.I. du Pont de Nemours \& Co. v. FTC, 729 F.2d 128, 139 (2d Cir. 1984) (noting the "fine distinction" between "oligopolistic pricing alone," which is permissible, and price changes by one player in a concentrated market serving as signals, picked up by its competitor). For this reason it has been considered impossible to outlaw consciously parallel pricing. See Clamp-All Corp. v. Cast Iron Soil Pipe Inst., 851 F.2d 478, 484 (1 st Cir. 1988) ("it is close to impossible to devise a judicially enforceable remedy for 
sum up in a simple legal rule. ${ }^{189}$ Antitrust law's unfortunate century-long flirtation with per se rules shows that clarity may best be achieved through the common law process. ${ }^{190}$

Interestingly, some of the facts that are proposed to be legitimate plus factors would require economic analysis to establish. ${ }^{191}$ It is not newsworthy to observe that economic analysis is a substantial aspect of a private antitrust suit in the modern era. Economic analysis is regularly employed on questions ranging from defining the relevant market to establishing antitrust injury. "In antitrust litigation, the factual complexity and economic nature of the issues involved require the presentation of economic expert testimony in all but a few cases." ${ }^{192}$ In the case of conspiracies under Sherman One, at least since Matsushita, economic principles have been imbedded in the governing substantive rule of law. ${ }^{193}$

A possible implication of defining the pleading requirement based on the substantive elements of the offense is that plaintiffs may be required, in the absence of the ability to make direct allegations of conspiracy, to produce an economic expert affidavit supporting their complaint. ${ }^{194}$ Justice

'interdependent' pricing."). But see Thomas A. Piraino, Jr., Regulating Oligopoly Conduct Under the Antitrust Laws, 89 MiNN. L. REV. 9, 15, 32-49 (2004) (arguing that conduct should be illegal if it is contrary to independent self interest); Alan Devlin, A Proposed Solution to the Problem of Parallel Pricing in Oligopolistic Markets, 59 STAN. L. REV. $1111,1143-50$ (2007) (proposing a solution to the inability to legally sanction consciously parallel pricing by means of methods involving "analogizing conscious parallelism in an oligopoly with unilateral contract", prohibiting "parallel price increases arrived at through barometric price leadership" and requiring "barriers to entry into the relevant market be shown to exist").

189. See William H. Page, Communication and Concerted Action, 38 LOY. U. CHI. L. J. $405,426-35$ (2007) (proposing a definition of plus factors that turns on the type of communication among competitors).

190. Cf. Leegin Creative Leather Prods., Inc. v. PSKS, Inc., 127 S. Ct. 2705, 2717-18 (2007) (where a practice can be both pro-competitive and anti-competitive, rule-of-reason analysis on a case-by-case basis is better than per se condemnation).

191. The observation that doctrine rejects the pure economic definition of conspiracy does not undermine this conclusion. Economic experts are able to apply their craft within the relevant doctrinal framework. See Brief of Amici Curiae Economists in Support of Petitioners at 8-9, Bell Atlantic Corp. v. Twombly, 127 S. Ct. 1955 (2007) (No. 05-1126), 2006 WL 2506633; Page, supra note 189, at 429 (arguing "most economists believe that [explicit communication] is usually necessary" to show agreement "in complex real-world markets").

192. John Lopatka \& William H. Page, Economic Authority and the Limits of Expertise in Antitrust Cases, 90 CORNell L. REv. 617, 617 (2005).

193. See Matsushita Electric Industrial Co. v. Zenith Radio Corp., 475 U.S. 574, 588 (1986) (requiring an evaluation of the "competing inferences of independent action or collusive action" from the facts alleged); $i d$. at 592 (emphasizing the economic irrationality of the story advanced by the plaintiffs).

194. Cf. Epstein, supra note 11, at 12-13 (noting that true but vacuous factual allegations at the motion to dismiss stage present starkly the economic question of what inference to draw from those facts). 
Stevens, in his Twombly dissent, raised just that specter. ${ }^{195}$ That is a dramatic result, but it is in reality the simple application of the Rule 8 standard in the context of a massively complex substantive legal scheme. ${ }^{196}$

\section{Recent Pleading Practice}

Twombly has had an impact extending far beyond the substantive Sherman One arena, evidenced by the number of citations the case has enjoyed among the lower courts since the opinion came down in May 2007. Within a year of its being handed down, Twombly has been cited by U.S. tribunals more than 4800 times. ${ }^{197}$ That number is more meaningful when compared to the three other antitrust cases decided in the 2006 Term by the Supreme Court-Weyerhaeuser, Credit Suisse v. Billing, and Leegin-all of which might have been thought to be higher profile than Twombly when certiorari was granted. ${ }^{198}$ Taken together, in approximately the same time period, those cases have been cited 70 times by U.S. tribunals. ${ }^{199}$ A better comparison that also paints a dramatic (if somewhat less so) picture, is to the other pleading cases from the 2006 Supreme Court Term, Tellabs, Inc. v. Makor Issues \& Rights, Ltd. ${ }^{200}$ and Erickson v. Pardus. ${ }^{201}$ Tellabs has informed the decisions of 186 tribunals since the opinion was issued, and Erickson has been cited by 1189 courts. ${ }^{202}$ This loose bundle of statistics tells at a minimum that Twombly is having an impact far beyond the scope of the Sherman One claim, with which it ostensibly deals. ${ }^{203}$

195. See Twombly, 127 S. Ct. at 1988 (arguing "the Federal Rules contemplate that pretrial matters will be settled through a flexible process of give and take, of proffers, stipulations, and stonewalls, not by having trial judges screen allegations for their plausibility vel non without requiring an answer from the defendant").

196. Cf. supra notes 90-94 and accompanying text (arguing that Form 9 does a poor job of demonstrating the manner of pleading claims more complex than simple negligence).

197. According to a Westlaw citation search run April 3, 2008. See also Dorf, supra, note 20 (describing the impact of Twombly by a citation-count comparison at three months from its issuance).

198. Weyerhaeuser Co. v. Ross-Simons Hardwood Lumber Co., 127 S. Ct. 1069 (2007); Credit Suisse USA LLC v. Billing, 127 S. Ct. 2383 (2007); Leegin Creative Leather Prods., Inc. v. PSKS, Inc., 127 S. Ct. 2705 (2007).

199. According to a Westlaw citation search run April 3, 2008.

200. 127 S. Ct. 2499 (2007)

201. 127 S. Ct. 2197 (2007).

202. According to a Westlaw citation search run April 3, 2008.

203. See In re Elevator Antitust Litigation, 502 F.3d 47, 50 n.3 (2d Cir. 2007) ("A narrow view of Twombly would have limited its holding to the antitrust context, or perhaps only to Section 1 claims; but we have concluded that Twombly affects pleading standards somewhat more broadly.") (citing authorities applying Twombly outside the Sherman One and outside the antitrust arenas); Thomas, supra note 16, at 7 (predicting "far-ranging ramifications to the impingement of the jury trial right in other types of cases"). Also, Sherman One itself boasts only 309 cites by tribunals over the past year, according to a Westlaw citation search run on April 3, 2008. 
The extent of its actual impact in the Sherman One arena is difficult to evaluate. This Article notes above that the idea of true "notice" pleading in the antitrust arena has something of an urban legend quality. ${ }^{204}$ Many preTwombly influential decisions exist in which courts have required pleading that would satisfy the Twombly standard. Judge Boudin's opinion in DM Research, Inc. v. College of American Pathologists ${ }^{205}$ is the leading preTwombly authority on pleading a Sherman One conspiracy. The court refused to sanction the fishing expedition that would entail from permitting a conclusory allegation of "conspiracy" to entitle the plaintiff to discovery to determine what facts demonstrated the conspiracy. "[T]he discovery process is not available where, at the complaint stage, a plaintiff has nothing more than unlikely speculations. While this may mean that a civil plaintiff must do more detective work in advance, the reason is to protect society from the costs of highly unpromising litigation.",206

In Car Carriers, Inc. v. Ford Motor Co. ${ }^{207}$ the Seventh Circuit rejected as insufficient the allegation that "defendants and their coconspirators entered into contracts and engaged in a continuing combinations [sic] and conspiracies to restrain trade in the business of providing haulaway motor transportation for new Ford automobiles.",208 The Car Carriers court was swayed by "the costs of modern federal antitrust litigation and the increasing caseload of the federal courts" in holding that the allegation of a legal conclusion was insufficient. ${ }^{209}$ In addition, Judge Posner wrote in Sutliff, Inc. v. Donavan Cos. ${ }^{210}$ that Conley "has never been taken literally."

204. See supra note 150 and accompanying text.

205. 170 F.3d 53,56 (1st Cir. 1999) (holding while this may mean that a civil plaintiff must do more detective work in advance, the reason is to protect society from the costs of highly unpromising litigation.").

206. Id. at 56 .

207. 745 F.2d 1101 (7th Cir. 1984).

208. Id. at 1104 (quoting the complaint).

209. Id. at 1106 .

210. 727 F.2d 648 (7th Cir. 1984) (Posner, J.).

211. Id. at 654. See also, e.g., Tal v. Hogan, 453 F.3d 1244, 1261 (10th Cir. 2006) (arguing that conclusory allegations are not sufficient to support an antitrust conspiracy claim); Univ. Life Ins. Co. of Am. v. Unimarc Ltd., 699 F.2d 846, 852 (7th Cir. 1983) (finding the allegations insufficient because plaintiffs failed to show likelihood of injury); In re Plywood Antitrust Litig., 655 F.2d 627, 641 (5th Cir. 1981) (supporting the argument that plaintiffs need particularized proof in order to establish damages); Larry R. George Sales Co. v. Cool Attic Corp., 587 F.2d 266, 273 (5th Cir. 1979) (stating that the requirements of pleading a claim under the Sherman Act can not be met by simple allegations); Heart Disease Research Found. v. Gen. Motors Corp., 463 F.2d 98, 100 (2d Cir. 1972) (dismissing a claim where simple claims of conspiracy or injury were insufficient without supporting facts); Five Smiths, Inc. v. Nat'l Football League Players Ass'n, 788 F. Supp. 1042, 1048 (D. Minn. 1992) (supporting the argument that allegations of conspiracy without particular facts are inadequate to state a claim); Fort Wayne Telsat v. Entm't \& Sports Programming 
Supreme Court's own recognition in Associated General Contractors, where allegations by a union of conduct by employers to undermine the union were rejected, that "in a[n] [antitrust] case of this magnitude, a district court must retain the power to insist upon some specificity in pleading before allowing a potentially massive factual controversy to proceed.,"212

The recent conclusion of the Second Circuit in In re Elevator Antitrust Litigation $^{213}$ that, after Twombly, allegations of parallel conduct coupled with conclusory allegations of a conspiracy-allegations nearly indistinguishable from those the same court had held sufficient in Twombly-is not path breaking in light of the depth of pre-Twombly precedent on conspiracy claims generally and Sherman One claims specifically. ${ }^{214}$ It is true, however, that the Second Circuit's approach to pleading Sherman One in Elevators is diametrically opposed to that court's approach prior to reversal in Twombly. ${ }^{215}$

The Ninth Circuit has reached post-Twombly a result not inconsistent with the pre-Twombly DM Research precedent. In Kendall v. Visa U.S.A., Inc., allegations that the defendants agreed, unaccompanied by allegations giving rise to an inference of an agreement, were insufficient to state a claim. ${ }^{216}$

In In re Late Fee and Over-Limit Fee Litigation in the Northern District of California, ${ }^{217}$ allegations of "lockstep pricing" of late fees, together with allegations of opportunity and incentive to collude and conclusory allegations of agreement, were insufficient to meet the Sherman One standard post-Twombly. ${ }^{218}$ The court also noted features of the complaint, including the conclusory nature of the conspiracy allegations and the pleading of facts, which themselves provided innocent explanations for the parallel conduct alleged, that should have encouraged dismissal under such cases as Sutliff or DM Research. In In re Graphics Processing Units Antitrust Litigation, the Northern District of California held that allegations of parallel pricing and parallel product releases were

Network, 753 F. Supp. 109, 113 (S.D.N.Y. 1990) (quoting Heart Disease for the proposition that conclusory statements without facts permit dismissal of antitrust claim).

212. 459 U.S. 519,528 n. 17 (1983). Justice Stevens, the dissenter in Twombly, wrote the opinion in Associated General Contractors.

213. 502 F.3d 47 (2d Cir. 2007).

214. See id. at 50-52 (rejecting the allegations as insufficient).

215. See supra notes $43-45$ and accompanying text (discussing the Second Circuit's original opinion in Twombly).

216. See Kendall v. Visa U.S.A., Inc., No. 05-16549, slip op. 2191-2194 (9th Cir. Mar. $7,2008)$.

217. 2007 WL 4106353 (N.D. Cal. Nov. 16, 2007).

218. Id. at *5. 
insufficient to survive a motion to dismiss post-Twombly. ${ }^{219}$ Those holdings would not be surprising even in the pre-Twombly world.

But Twombly does not spell the end of Sherman One litigation. ${ }^{220}$ This Article discusses above the sorts of plus factors that should be sufficient to permit a claim to proceed. ${ }^{221}$ Plaintiffs in Pennsylvania and California have been able to clear the hurdle. In In re OSB Antitrust Litigation, the Eastern District of Pennsylvania held that allegations of secret meetings and a published price list were sufficient to survive the motion to dismiss. ${ }^{222}$ Likewise, in In re Rubber Chemicals Antitrust Litigation, allegations of parallel pricing, together with allegations of meetings, including who was present and how they were involved in fixing prices, were sufficient. ${ }^{223}$

\section{CONCLUSION}

Potential criticisms of the approach to pleading the Sherman One claim discussed in this Article abound. The application of Rule 8, according to its terms, to the substantive antitrust rules has the effect of making more difficult the task for private plaintiffs in entering the litigation arena. That is more so because antitrust conspiracy claims, at least, involve conduct that is secretive in nature. The defendants are also the gatekeepers of the kind of information necessary to satisfy the pleading requirement. Those two factors produce dramatic information asymmetries. Justice Stevens discussed in his dissent (in a portion which Justice Ginsburg did not join) that the result is to protect "antitrust defendants-who in this case are some of the wealthiest corporations in our economy - from the burdens of pretrial discovery."224 Those concerns ignore fundamentals about the legal and regulatory scheme.

Telecom regulation and antitrust have had an uneasy relationship since 1996. When the Telecom Act was passed, it was predictable that the requirements of interconnectivity would present exclusionary conduct concerns, as competitors sought to enter new markets and incumbents

219. 2007 WL 2875686 , at $*^{*} 10-* 11$ (N.D. Cal. Sept. 27, 2007) (noting that Plaintiff's allegations could lead to a conclusion of coincidence rather than conspiracy).

220. But cf. Thomas, supra note 16 (draft at 7-8) (arguing that after the trilogy of summary judgment decisions in 1986, which included the Matsushita decision, "the courts exponentially increased their use of summary judgment," particularly in antitrust cases, and that the same should be expected for the motion to dismiss after Twombly).

221. See supra notes 165-198 and accompanying text (discussing pleading plus factors).

222. 2007 WL 2253419 , at *3 (E.D. Pa. Aug. 3, 2007) ("Plaintiffs in the instant case have alleged facts that strongly suggest - and are 'not merely consistent with'-a pricefixing conspiracy.").

223. 504 F. Supp. 2d 777, 790 (N.D. Cal. 2007) (“Plaintiffs' allegations against Welch are specific and substantial enough to state a cognizable claim.").

224. Bell Atlantic Corp. v. Twombly, 127 S. Ct. 1955, 1989 (2007) (Stevens, J., dissenting). 
sought to keep them out. So they did, and in Verizon Communications Inc. v. Law Offices of Curtis V. Trinko, ${ }^{22 S}$ the Supreme Court held there was no place for a Sherman Two suit in the regulatory scheme. ${ }^{226}$ One might wonder whether the same rule could be applied to the Sherman One claim raised in Twombly. The Supreme Court noted that some of plaintiffs' allegations supporting their conspiracy claims were the result of the changing regulatory scheme. That being so, perhaps, like Sherman Two, the Sherman One claims should be approached with particular circumspection in that particular industry.

What is clear about antitrust claims in general, and their application in this industry specifically, is that the substantive law imposes a heavy burden on plaintiffs. It does so to protect against the direct harm to individual defendants and the broader economic consequences of punishing commercial activity. Unlike the civil rights claims at issue in the Supreme Court's other recent pleading cases, where individual dignity of the plaintiffs is implicated, private suits under the antitrust laws primarily serve the purpose of vindicating broader economic interests. The remedy available serves as an incentive-perhaps a poorly designed on ${ }^{227}$ - to encourage private plaintiffs to incur the expense. But it is the public right at stake, not the individual remedy, that is the primary thrust of the cause of action. Thus, imposing strict standards for private claims as a matter of substantive antitrust law-with the effect of making it harder to survive the procedural hurdle of a motion to dismiss ${ }^{228}$-is a necessary protection against misaligned incentives. That check would be undermined by a contrary rule that allowed claims to proceed despite the failure to plead elements. The Twombly Court struck a substantially correct balance.

225. 540 U.S. 398 (2004).

226. See id. at $412-16$ ("The $1996 \mathrm{Act}$ is, in an important respect, much more ambitious than the antitrust laws. It attempts 'to eliminate the monopolies enjoyed by the inheritors of AT\&T's local franchises.' Section 2 of the Sherman Act, by contrast, seeks merely to prevent unlawful monopolization. It would be a serious mistake to conflate the two goals.").

227. See Huffman, supra note 2, at 114 ("little incentive exists for private plaintiffs to limit their claims, so the remedy does not result in too great of deterrence by the defendant.").

228. Cf. Twombly, $127 \mathrm{~S}$. Ct. at 1975 (Stevens, J., dissenting) (accusing the majority of "an interpretation of Federal Rule of Civil Procedure 12(b)(6) that seems to be driven by the majority's appraisal of the plausibility of the ultimate factual allegation"). 